\title{
Consultant Identification on Critical Risk Factors Affecting Construction Project Execution in Ghana
}

\author{
Atta Agyeman junior \\ University of Education Winneba \\ College of Technology Education Kumasi \\ Timothy Adu Gyamfi \\ Faculty of Built and Natural Environment \\ the Department of Building Technology \\ kofridual Technical University \\ King Solomon Akorli \\ Faculty of Built and Natural Environment \\ the Department of Building Technology \\ kofridual Technical University
}

\begin{abstract}
The consultants are front liners in execution of construction project and their perceived critical risk factors affecting construction project delivery is wealth considered and being aware to such hindrance will ensure efficient and effective project management technique to manage such risk should it occur. The purpose of the study was to identify critical risk factors affecting construction project delivery in Ghana. The study objective was to identify consultant's perception on critical risk factors hindering construction execution and how to manage the risk. The study adopted a quantitative approach involving a cross-sectional design using survey, questionnaires administered to a population of 355 consultants of the Ghana Consulting Engineering Association (GCEA). Descriptive statistics, cross tabulations, factor analysis were used to analyse the resulting data. The study found that the most critical risk factors hindering construction delivery included high performance expectations, tight project schedule, poor program planning, excessive approval procedures, and bureaucracy of government. The study has establish that For all government funded projects, the main financial risk was the delay in payment and bankruptcy of stakeholders and main source of time overrun risks was enlargement of the project scope. The study further shown that the management of time schedule risk and financial risk included setting and agreeing on reasonable time lines, prompt payments on the part of stakeholders and obtaining reliable source of project funding, government to reduce the interest rates in order for stakeholders in construction projects to secure loans to fund projects respectively.
\end{abstract}

Key Words: Risk Management, Risk, Consultants, Risk Factors, Project Execution.

\section{INTRODUCTION}

General risk models accept the fact that production is associated with uncertainties, which may hinder yielding optimum output (Chapman, 2001, Chileshe, 2004). These uncertainties, also known as risks, are typically described as events or conditions that may have an impact on the objectives of production (Ward \& Chapman, 2003). Risks therefore concern the deviation of one or more results of one or more future events from their expected values. The impacts of risks may be positive or negative, but general usage tends to focus only on potential harm that 
may arise and/or accrue from incurring a cost or failing to attain some particular benefits. (Muller,2010 Ijaola, 2012). A Project risk may, thus, not necessarily be negative, such as increased costs or decreased quality. A risk can also be positive, for example, a new valuable product features due to the use of new technology or opening up a new market segment due to some project adjustments (Ijaola, 2012; Eshan et al., 2014). Studies in Ghana, have shown that the construction industry is mostly challenged by financial risks which stems from overdue payments to Contractors, Consultants, Suppliers and Subcontractors (Agyakwa-Baah; 2009; Frimpong et al., 2003; Odonkor, 2011). These studies also indicated that the industry is also exposed to political, natural, construction and design risks, but they are heightened at the construction stage. Studies, including Agyakwa-Baah (2009) has identified brainstorming as the commonest risk identification method, whereas other studies such as Frimpong et al. (2003) and Odonkor (2011) identified interviews, expert judgement and observations as the main risk identification methods in Ghana's construction industry.

Precisely, some of the main duties of the consultant, according to Dadzie et al. (2012), are reviewing and updating design details, monitoring contractor's operations to ensure timely commencement of operation, reviewing contractor's programme, carrying out quality control tests, as well as reviewing contractor's monthly invoices and certifying for payment. This paper is part of bigger study that focuses on consultants' perspective on risk management practices in Ghanaian's construction. This study therefore focuses on consultant's identification of critical risk factors affecting construction project execution in Ghana: The aim of the study is to identify critical risk factors affecting construction project execution in the opinions of consultants. The objectives of the study is to identify critical risk factor hindering construction delivery in Ghana and suggest how the risk could be managed.

\section{Statement of the Problem}

Construction industry is highly risk prone, with complex and dynamic project environments creating an atmosphere of high uncertainty and risk (Eshan et al., 2010). The industry is vulnerable to various technical, socio-political and business risks. As a result, construction firms bear various failures, such as, failure of abiding by quality and operational requirements, cost overruns and uncertain delays in project completion (Eshan et al., 2014). An effective system of risk assessment and management for construction industry, therefore, remains a challenging task for the industry practitioners. Given that consultants' perspectives in their field of specialisation directly influences the success of the project (Dadzie et al., 2012), it is important to examine their orientation on their perception on risk based on their experience and knowledge. Moreover, there has been many research on risk in financial, fall in the construction industry, construction project work and application to manufacturing. However, the few researches on risk in Ghana failed to address risk from stakeholder's perspective. This study, therefore, seeks to address this gap in literature by identifying critical risk factors affecting construction project execution in Ghana: The consultants' perspective.

\section{Definition of The Concept Of Risk}

Generally, the concept of risk is encapsulated in potential losses, which refer to the probability of losses occurring (Carter \& Doherty, 1974; Flanagan \& Norman, 1993). Bernstein (1996) also noted that probability is the key to determining and managing risk. Jones (2006) further established that a risk is the probable frequency and probable magnitude of future loss. In this concept, risk is seen as a probability, which refers to the continuum between absolute certainty and impossibility. Risk is also addressed as both a frequency and a magnitude component, which suggests that the frequency of the risk can have relations to the magnitude and probability of incurring a future loss (Jones, 2006). Thus, in spite of significant differences 
between field of inquiry and application, risk is generally defined in probabilistic terms and accordingly at the intersection between achievements of instrumentally constructed means to goals and the likelihood of failure and negative outcomes.

Based on the ISO 31000:2009, Hopkin (2012), on the other hand, conceptualises risk not in terms of probability of loss, but the effect of uncertainty on objectives, thus causing the word risk to refer to positive possibilities as well as negative ones. However, this has been criticised an unnecessary attempt to alter a universally understood word in a way that causes considerable confusion and that as always, the word risk should be used to refer only to undesirable possibilities (Popva-Clark, 2011). Thus, Hopkin (2012) establishes that a risk is generally the probability of an unwanted event or the cause of an unwanted event which may or may not occur. Similarly, Popva-Clark (2011) also maintains that risk is the potential that a chosen action or activity, including the choice of inaction will lead to a loss or an undesirable outcome. The notion implies that a choice having an influence on the outcome sometimes exists or existed.

Calycamp (2012) emphasised that any concept of risk is built on fundamental concepts of chance, likelihood, or probability, and that the probability concept in risk is conceived as a combination of frequency-based calculation and a degree of belief. Thus, in any field or business, risk is constructed as an objective structure-agency phenomenon that influences the possibility that a target or goal is achieved. Hubbard (2009)also asserted that risk applies equally well regardless of its conceptualisation within investment, market, credit, legal, insurance, information risk, or any of the other risk domains that are commonly dealt with in business, government, and life

\section{Risk in Construction Projects}

Akintoye and Macleod (1997) have defined risk in relation to construction as a variable in the process of a construction project whose variation results in uncertainty as to the final cost, duration and quality of the project. Due to construction projects' complexity and uniqueness, not only does the number of risks present invariably go beyond those found in other industries, but the risks also change from one construction project to the next (Panthi et al., 2009).Risk is an inevitable phenomenon in an industry as dynamic as construction, irrespective of the size of the project. For example, Zou et al. (2006) maintain that in construction, decisions including the scope of the project, the quality standards, time, purchases and costs, communication channels and the contract management options vary from one project to the next.

Smith (2003) establishes that the construction industry is subject to more risks because of distinctive characteristics of construction such as financial intensity, complex procedures, lengthy duration, offensive environment and dynamic arrangements of organizations. Many other factors affect the level of risk including situation of market, level of competition, size of the project, political and economic variations, and expertise of parties (Flanagan and Norman, 1993; Akintoye and MacLeod, 1997; Smith, 2003; Smith et al., 2006). These risks are distributed through the entire project life cycle and some of the risks may happen at more than one phase.

There are, however, arguments regarding the degree of risk in different phases of a construction project. Hayes `et al. (1986) and Godfrey (1996) assert that the greatest degree of risk exist in the earliest phase of the project when available information about the project is the least. Chapman and Ward (1997), as well as Hassanein and Afify (2007) similarly stated 
that risk is at its peak in the conceptual phase. However, with Zou et al. (2006) contradicted that the construction phases to be more risky phase than the feasibility (conceptual) phase. In further contradiction, Wang et al. (2004) argue that risks of construction projects increase as the project progresses and this illustrates that each phase of the construction project includes more risks than the previous one. However, Ghahramanzadeh (2013) counter-argued that this greatly depends on the type of the project, the type of the contract, and type of the risks.

A broad classification of the types of risks, as indicated by Flanagan and Norman (1993) includes pure/static risks, which are relating only to potential losses with no potential gain, and dynamic/speculative risks with possibility of potential gains as well as losses. Smith and Bohn (1999), conversely, classified risk into internal and external risks. They defined internal risks as the ones generated inside the project and more probable to be controlled whereas external risks are originated outside of the project and therefore mostly not controllable. From yet another perspective, Smallman (1999)categorised construction risks into direct and indirect risks, whereby internal risks include human, organisation and technological (HOT) risks and indirect risks cover regulatory, infrastructural and political (RIP) risks. Ghahramanzadeh (2013) compared and found similarities between Smith and Bohn's (1999) classification of internal and external risks and Smallman's (1999) concept of direct and indirect risks, as both classifications present the extent to which the risks are specific to the project.

Hillson and Murray-Webster(2004) maintained that risk can be categorised into epistemic risks, aleatory risks, dynamic risks, and static risks. An epistemic risk, according to Hillson and Murray-Webster(2004), is more related to a lack of knowledge about matters having an influence on the outcome. Sohizadeh et al. (2011) also note that the lack of information may result from lacking the essential knowledge or using the wrong methods and tools to identify or assess risks. Thus, epistemic uncertainty may be described as an unknown event from an unknown set of possibilities (Sohizadeh et al., 2011). An aleatory risk is a risk that could be regarded as random, estimated with probabilities and consequences to a set of possible known outcomes, but still, in the end, with a random outcome. In construction, Kishk and Ukaga (2008) maintain that epistemic risk is introduced whenever assumptions are made about the project. Such assumptions are made due to incomplete knowledge of the environment to be absolute certain. Proske (2008) therefore asserts that risks must be seen in terms of the acceptable rate of losses, since alaetory uncertainties can always lead to some level of losses.

Adams (2008) also categorised risks into subjective and objective. Subjective risks are qualitatively identified based on the experience and knowledge of the analyst, whereas objective risks are quantitatively established through calculation of their impact and likelihood. Adams (2008) believes that most of the construction project'srisks are subjective because there are not sufficient historical data for their quantitative analysis and should be analysed according to analyst's judgment.

The PMI (2004) established that construction-specific risks can be categorised into technical risks, organizational risks, project risks and external risks (TOPE risks), whereas Wiguna and Scott (2006) opined that in industry-specific risks in construction cover economic and financial risks, external and site condition risks, technical and contractual risks, and managerial risks.

Al-Bahar and Crandall (1990) establishes that risks in construction can be categorised under six thematic areas, which are natural disasters, physical risks, financial and economic risks, 
political risks, design risks and construction related risks. According to Adams (2008), some of the risks are associated with the construction process are fairly predictable or readily identifiable while others may be totally unforeseen. For example, acts of God or natural disasters, such as floods and earthquakes may be not be as predictable or controlled as other types of risks, such as theft, inflation, design and other pollution. However, these risks have implications for procurement, as they may increase costs, damage, changes in project design, or equipment failure.

Zou et al. (2006), on the other hand, identified fifty-one construction risks, but noted that twenty of them were the major risk factors, which could be classified under five broad thematic areas of cost, time, quality, environment and health. Specifically, Laryea (2011) identifies tight project schedule, design variation, excessive approval procedures and high performance/quality expectations as the top five construction risks. On the other hand, general safety, inadequate site information, disputes, price inflation and noise pollution were the bottom five construction related risks.

Jean-Lou et al. (2011) note that construction risks are mainly related to contractors, clients and designers, with few related to government bodies, subcontractors/ suppliers and external issues. These risks are also interrelated in such as way that a risk in one classification can cause impairment in the project completion. In this respect, Mumtaz et al. (2011) maintain that construction risks spread through the entire project life cycle and many risks occur at more than one phase, with the construction stage as the most risky phase, followed by the feasibility stage. Thus, Razaque et al. (2012) suggest an integrated approach to identify potential risks in time, and to make sound preparations for carrying out safe, efficient and quality construction activities under a well-structured risk management programme.

Risks, irrespective of their type, should be managed in order to decrease or remove the negative outcomes and discover the opportunities at the earliest chance for maximising the benefits realised from them (Oladinrin et al., 2013). At the outset of a project, all risks lie with the client but depending on the selection of the procurement system and the contract for any construction project, the risks may be transferred to other parties than just the client during the project. The impacts of risks, in terms of frequency and intensity, can therefore vary based on the procurement option and the type of project (Noor \&Tichacek, 2009; Oladinrin et al., 2013).

\section{Study Design}

\section{RESEARCH METHODOLOGY}

An important aspect of any research is the design. It is the logical sequence that connects the empirical data to the initial questions of the study and, ultimately, to its conclusions (Sarantakos, 2005). This study adopted a quantitative research approach, which is the numerical representation and manipulation of observations for the purpose of describing and explaining the phenomenon that those observations reflect (Babbie, 2005). This allowed the collection of quantitative data and also enabled the use of quantitative methods in the analysis of data.

The research designs adopted were the descriptive and cross-sectional designs. Key (1997) reports that methods involved in a descriptive study design range from the survey which describes the status quo, the correlation study which investigates the relationship between variables, to developmental studies which seek to determine changes over time. Sarantakos (1998) confirms that descriptive research aims at describing social systems, relations or social 
events and providing background information about the issue in question and also to stimulate explanations. A descriptive design was therefore adopted because the study ultimately sought to find consultants' perspective on general understanding of risk in construction industry in Ghana.

\section{Study Sample}

The target population was 722 members of the GCEA. However, a sample was taken due to the relative short period for the completion of the study, as well as resource constraints and the fact that a representative sample could be generalised for the entire population (Creswell, 2003). According to Krejcie and Morgan's (1970) sample size estimation table, a sample of 250 and adjusted for non-response by $42 \%$ of 250 is 105 which made up of 355 is representative of a population of 722. The underlying construct for Krejcie and Morgan's (1970) estimation is based on equal population proportions for consultants and non-consultants in the study population, as well as a t-statistic of 1.95 at an alpha level of 0.05 .

\section{Sampling Procedure}

The calculated sample of respondents was selected using the simple random method; specifically the lottery method. The sampling frame consisted of a numbered list of all the members of the GCEA. The computer software, Q-Basic was programmed to generate 355 random numbers from 1 to 722 and the corresponding names to the sampling frame were selected.

\section{Instruments for Data Collection}

Questionnaires were used to solicit primary data from the consultants, because the study assumes that these groups of people are literate and can therefore read, understand and also answer the items on the questionnaire accordingly. Questionnaires were also employed by Chileshe and Yirenkyi-Fianko (2011), Buertey et al. (2012) and Adu Gyamfi and Boadaa (2015) in their studies on risks related issues in the Ghanaian industry.

\section{Pre-test}

The instruments for data collection were tested in one purposively selected consultant in construction firm in the Ashanti Region. This was done to serve as the preliminary testing of the research questions for their ability to generate the needed responses for the study. The purpose of the pre-test was to enable the researcher to make necessary changes to items which may be inappropriate, determine the level of ambiguity of the questions for corrections and determine the percentage of responses. Ambiguous items were modified and inappropriate items, made appropriate. The pre-test therefore enabled the researcher to revise the contents of the questionnaire thereby revising the instruments to achieve the reliability and validity standards required in scientific research.

Validity is the degree to which a test measures what it is supposed to measure. The researcher tested the face and content validity of the questionnaire. Face validity refers to the likelihood of a question being misunderstood or misinterpreted. Content validity refers to whether an instrument adequately covers all the topics concerned. The validity of the instrument was established through expert opinions, literature searches, and pre-testing of the questionnaire.

Reliability is a measure of the degree to which a research instrument yields consistency in its results or data after repeated trials. The questionnaire was administered on the same group of subjects twice in the pilot study with a two week grace period between the first and the second 
test and the coefficient of reliability from the two tests correlated. The reliability test yielded Crombach alpha of 0.89 .

\section{METHODS OF DATA ANALYSIS}

The data was cleaned and checked for reliability using statistical tools in Statistical Product for Service Solutions (SPSS). The study employed descriptive statistical tools to analyse demographic characteristics of respondents. Cross tabulations, and factor analysis.

\section{Working experience of the respondents}

\section{RESULT AND DISCUSSION}

The working experience of the respondents was also analysed based on the years they've worked as consultants and the number of projects they've worked on. This is presented in Table 1

Table 1: Working experience of consultants

\begin{tabular}{lllllll}
\hline \multicolumn{2}{l}{} & & & & & \\
Variables & $\mathrm{F}$ & Min & Max & Mean & Std. error & $\begin{array}{c}\text { Std. } \\
\text { Deviation }\end{array}$ \\
\hline $\begin{array}{l}\text { Years of experience in } \\
\text { the } \\
\text { industry }\end{array}$ & & & & & & \\
& 250 & 2.00 & 21.00 & 7.3080 & .33951 & 5.36809 \\
$\begin{array}{l}\text { Number of projects } \\
\text { worked on }\end{array}$ & 250 & 5.00 & 80.00 & 32.2120 & 1.66239 & 26.28465 \\
\hline
\end{tabular}

Source: Field survey 2015

From Table 1, the consultants had worked on their jobs from two (2) to 21 years with an average of 7 years (mean $=7.30, \mathrm{~S} . \mathrm{E}=0.33$ ). The minimum number of projects that the consultants had worked on was five and a maximum of 80 . This indicated that the respondents were experienced in terms of the years of working and the quantity of projects worked-on. Thus, their responses on the risk management in the construction industry were validated by the virtue of their working experience.

Table 2: Types of projects worked on by supervisors

\begin{tabular}{lcc}
\hline Types of projects & Frequency & Percent \\
\hline Residential homes and buildings & 170 & 47.6 \\
Government roads & 80 & 22.4 \\
Private residential and school building & 79 & 22.1 \\
Commercial houses & 28 & 7.8 \\
\hline Total & $357^{*}$ & 100.0
\end{tabular}

${ }^{*}$ Multiple responses were given; sample size $\mathbf{= 2 5 0}$

Source: Field Survey, 2015

The types of projects that the consultants usually work on were also analysed by the study using descriptive statistics. According to Table 2, some of the respondents worked on multiple types of projects, but the typical projects which they worked on were elicited. It was shown 
that 47.6 percent of the respondents worked on residential homes and buildings, 22.4 percent worked on government funded road works, 22.1 percent worked primarily on government funded school buildings and 7.8 percent usually worked on commercial houses. This indicated that most of the consultants worked on government funded projects, thus, the government was indirectly mentioned as the biggest client for the consultants.

\section{Identification of critical risk factors affecting construction project}

The respondents were asked to indicate the critical risk factors affecting construction project in Ghana. The result is shown in table 3 below

Table 3: Critical risk factors

\begin{tabular}{|c|c|c|c|c|}
\hline \multirow[b]{2}{*}{ Factors } & \multicolumn{4}{|c|}{ Component } \\
\hline & 1 & 2 & 3 & 4 \\
\hline \multicolumn{5}{|l|}{ Performance factors } \\
\hline High performance expectations & .874 & .122 & .456 & .064 \\
\hline Tight project schedule & .781 & .236 & .430 & .099 \\
\hline Poor structural design & -.195 & -.097 & .115 & .954 \\
\hline \multicolumn{5}{|l|}{ Labour and skills } \\
\hline Unavailable skilled labour & -.738 & .000 & .313 & .312 \\
\hline Unavailable professionals & -.696 & .156 & -.066 & .149 \\
\hline \multicolumn{5}{|l|}{ Planning } \\
\hline Poor schedule planning & -.268 & .675 & .486 & .266 \\
\hline Poor program planning & .184 & .901 & .244 & -.042 \\
\hline \multicolumn{5}{|l|}{ Approval and procedures } \\
\hline Excessive approval procedures & .748 & .325 & -.331 & .404 \\
\hline Bureaucracy of government & .262 & .865 & -.349 & -.018 \\
\hline Incomplete approvals & -.183 & .637 & .008 & .464 \\
\hline \multicolumn{5}{|l|}{ Variations and changes } \\
\hline Variations by client & .216 & .181 & .930 & -.125 \\
\hline Design variation & .011 & -.141 & .862 & .443 \\
\hline $\begin{array}{l}\text { Variations in } \\
\text { programme }\end{array}$ & .183 & .402 & .087 & .877 \\
\hline Eigenvalues & 4.180 & 3.133 & 2.357 & 1.590 \\
\hline Total variance explained & 32.153 & 24.104 & 18.131 & 12.228 \\
\hline Cumulative variance explained & 32.153 & 56.357 & 74.388 & 86.616 \\
\hline
\end{tabular}

Source: Field survey, 2015 
Using factor analysis, thirteen items on construction-related risks were subjected to Principal Component Analysis (PCA). From the initial solution, an inspection of the correlation matrix revealed that 89 percent of the matrices had coefficients of 0.3 and above, indicating that the data do not violate correlation strength assumption. The Kaiser-Meyer-Oklin value was 0.614, exceeding the recommended value of 0.6 and the Barlett's Test of Sphericity was significant (pvalue $=0.000<0.05$ ), supporting the factorability of the correlation matrix. PCA revealed the presence of four components with Eigen values exceeding one, explaining 32.2 percent, 24.1 percent, 18.1 percent and 12 percent of the matrix respectively.

The command to sort the component loading in a descending order resulted in the arrangement of the items as shown in Table 4.7. The results showed that the most critical risk factor of the construction industry from the perspective of the consultants was high performance expectation of clients. This was indicated with an eigenvalue of 0.874 , in 'component 1', followed by tight project schedule, with eigenvalue of 0.781 , excessive approval procedures, inadequate skilled labour and under-qualified professionals. It was therefore deduced that the most important risk factors of the construction industry according to the consultants, were internal to the construction industry.

The factor analysis identified five broad categories of factors that pose risks to construction industry. Based on the broad categories, performance factors were found to be most influential in the construction industry. Two sub-factors of the performance category, high performance expectations and tight project schedule had the highest eigenvalues.

The study did not assume uniformity in risks across the different phases of construction projects. The variations and intensity of risks which pertain to the various phases of the projects were solicited from the consultants' perspectives. In terms of financial risks, the consultants identified three major sources of risks to the construction industry. The results indicated that the most emphasized financial risk had to do with delays in payments and release of funds for construction projects (73.9\%). Following this was the bankruptcy of stakeholders $(16.3 \%)$ and corruption in procurement $(9.6 \%)$ as shown in figure 1 . From the consultants' perspective, therefore, the possibility of inaccessible financial markets poses the greatest financial risk. For all government funded projects, the main financial risk that consultants indicated was the delay in payment and release of funds.

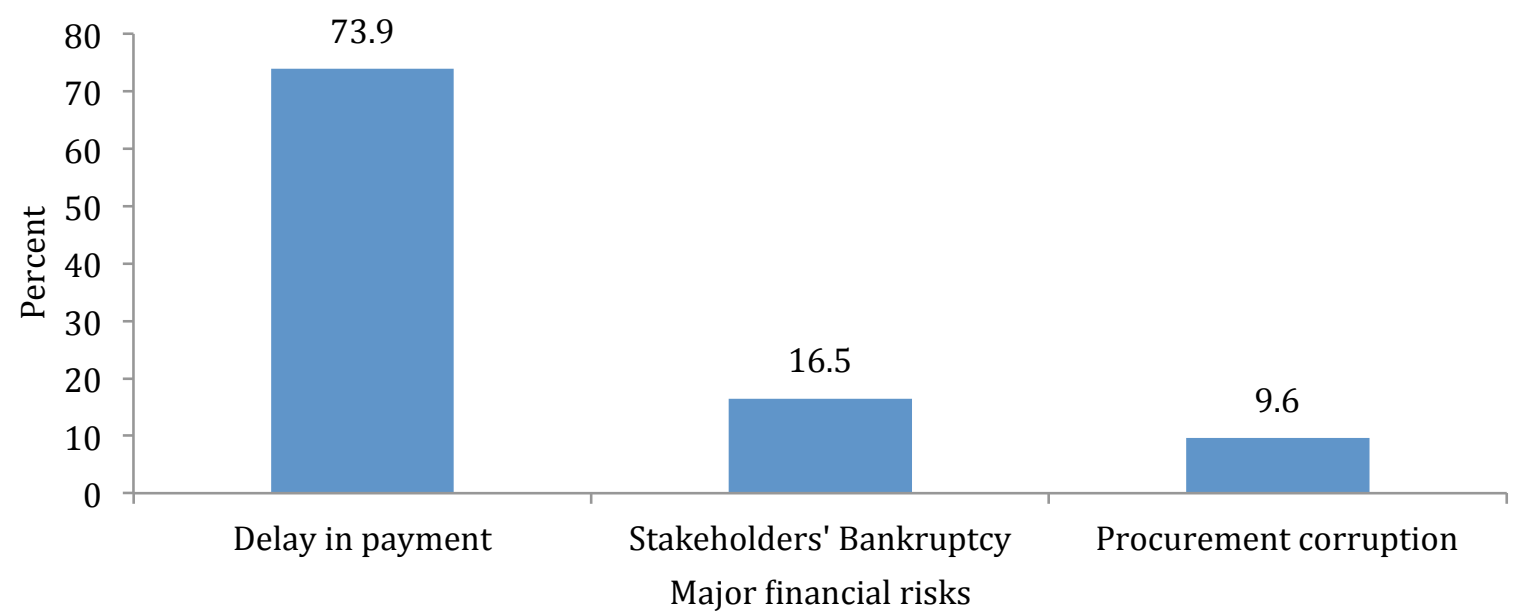

Figure 1. Major financial risks in the construction industry Source: Field survey, 2015 


\section{Time schedule risk}

The time schedule related risks were also analysed by the study. From figure 2 . The results were disaggregated by the types of projects in order to identify the relations between the risks and the different types of projects worked on by consultants. Three main time schedule risks emerged from the perspectives of the consultants. Accordingly 58.2 percent of the respondents, enlargement of the scope of the project was the main source of time overrun risks. This was typical of projects involving residential and private establishments, as well as government contracted road projects. The shortening of time schedule for projects was also captured as one of the major risks of time challenges in projects. Perera et al.'s (2009) research ranked scope change and tentative drawings as the two most influential risks in construction projects. Thus, the results in this study confirm that scope change could be critical to construction projects. Pourrostam and Ismail (2011) also identified delays as pertinent to construction projects. Their research also found that the negative effects of delay were time and cost overrun, disputes, arbitration, total abandonment and litigation.

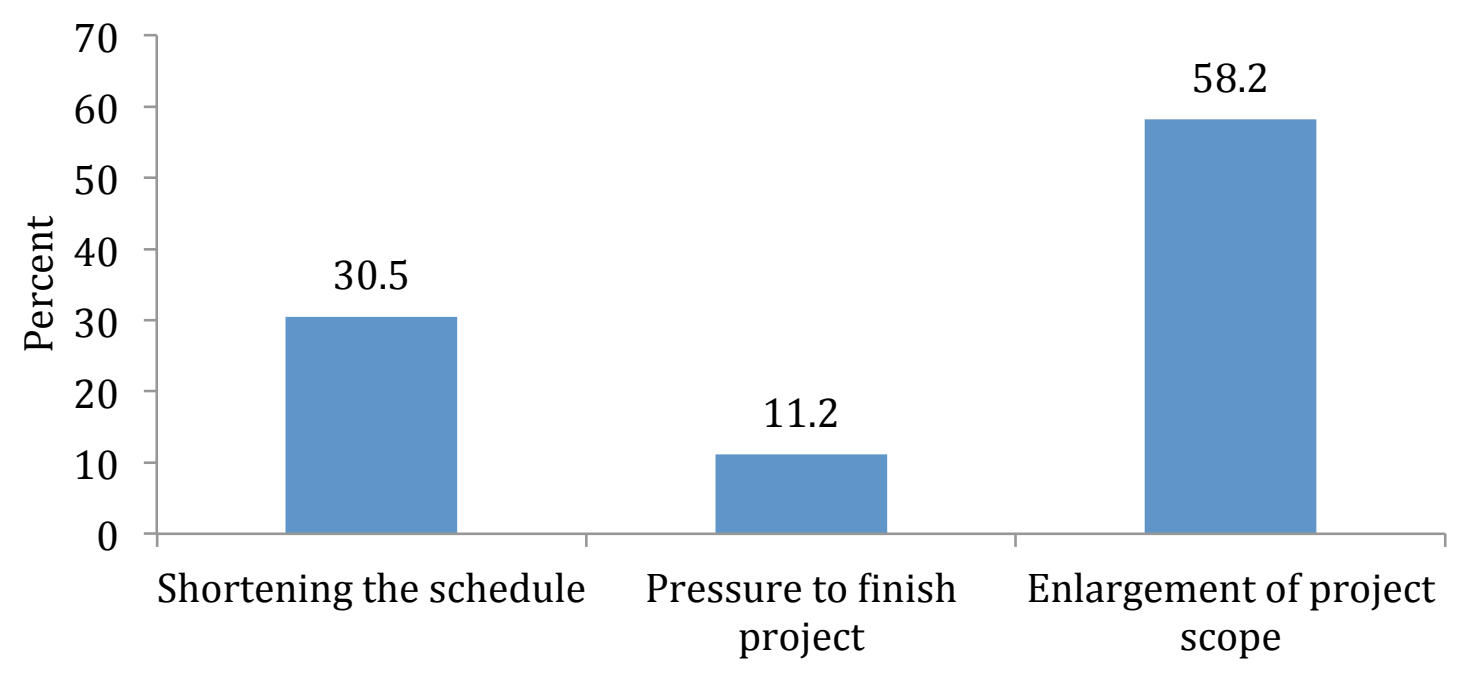

Time schedule risks

Figure 2: Major time-schedule risks in construction Source: Field survey, 2015

\section{Consultants' perspective on managing critical risk factors in construction}

The consultants were asked of their opinions about how to manage some critical risk factors in the construction industry. Their perspectives were sought on the premises that they had significant working experience in their varied fields of expertise, which would invariably influence their opinions. According to the study, financial risks, were most pertinent to the construction industry. In relation to that, the perspectives of the consultants on the risk management of critical risk factors were explored. The result is shown in Figure 3. 


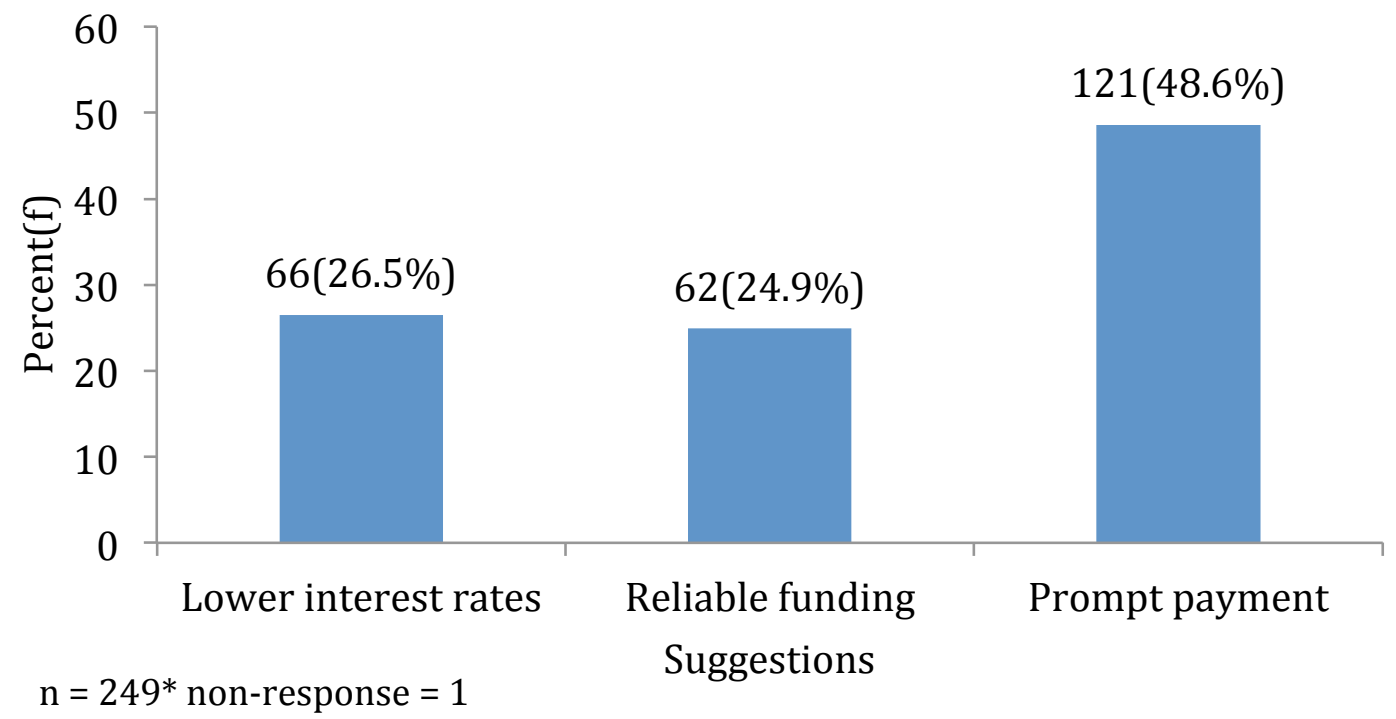

Figure 3: Suggestions to manage financial risks in construction Source: Field survey, 2015

The consultants' perspectives on managing the financial risks are listed, in multiple responses. It was shown that 48.6 percent of the responses given instigated for prompt payments on the part of stakeholders. The other suggestions made to improve the management of financial risks included obtaining reliable source of project funding and for the government to reduce the interest rates in order for stakeholders in construction projects to secure loans to fund projects. These were indicated by 24.9 percent and 26.5 percent of the responses respectively.

Again, in the quest of consultant perspectives on managing critical risk factors in construction such as time schedule risk. The result is shown in figure 4.The management of risk associated with time schedule included setting and agreeing on reasonable time lines (47.9\%) avoiding delays in payment (19.4\%) and teamwork (19.4\%). Others $(13.3 \%)$ also pointed out that budgeting for contingency funds would help reduce delays in projects and risks associated with time schedules.

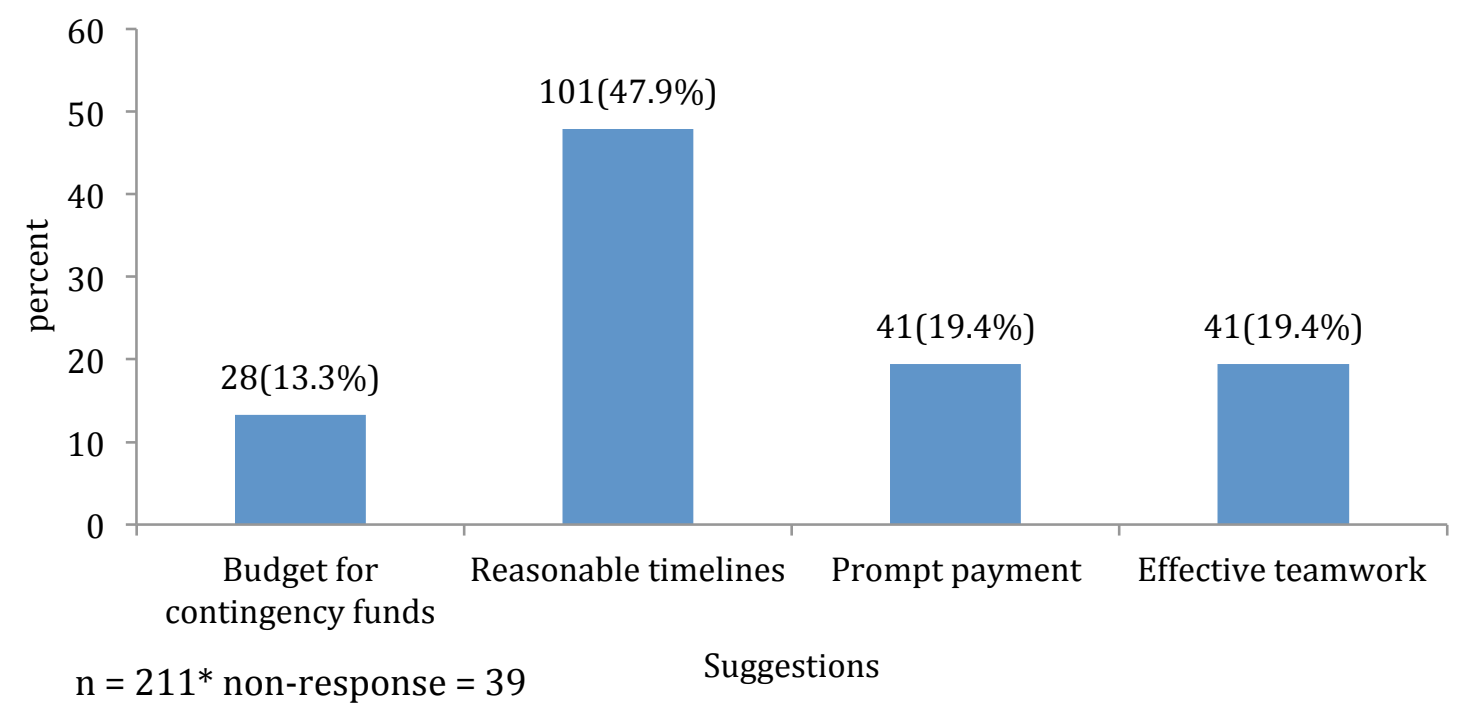

Figure 4: Suggestions to manage schedule time risks in construction Source: Field survey, 2015 


\section{CONCLUTION}

The risk associated with construction industries in their quest to deliver in their area of specialisation are many, this is not exception to consultants in this field. The study were conducted to find out consultant opinion on critical risk factors that challenge their performance in delivering in construction industry in Ghana. The consultants revealed that the most critical risk factors hindering construction delivery included high performance expectations, tight project schedule, poor program planning, excessive approval procedures, bureaucracy of government, variations by client, and design variation. For all government funded projects, the main financial risk that consultants indicated was the delay in payment and bankruptcy of stakeholders, again enlargement of the scope of the project was the main source of time overrun risks. The management of risk associated with time schedule included setting and agreeing on reasonable time lines and prompt payments on the part of stakeholders. The other suggestions made to improve the management of financial risks included obtaining reliable source of project funding and for the government to reduce the interest rates in order for stakeholders in construction projects to secure loans to fund projects.

\section{RECOMMENDATIONS}

- There should be prompt payments on the part of stakeholders in order to reduce financial risks.

- Consultants should as a matter of urgency strengthen the maintenance of proper structural integrity and proper calculation of bending moment to improve the management of design risks in construction.

- Consultants should engage in a more effective risk monitoring in order to identify any residual risks that may pertain to the construction projects for their subsequent management.

\section{ACKNOWLEDGEMENTS}

My greatest thanks go to Jehovah God for his divine assistance throughout this study. Also, I wish to express my profound gratitude to all those who have contributed to the success of the study especially Dr. N.A. Kheni who was my academic supervisor, for his precious and valuable time despite his busy schedules.

I am very grateful to my dearest wife for her understanding and tolerance when undertaking this study. I am grateful to all authors whose books and publications I referenced. Finally, I appreciate the assistance given to by Lectures at Department of Design and Technology Education. I would also like to express my profound gratitude to my honourable sister Mrs. Rebecca Serwaa for her support and encouragement

\section{References}

Adams, F. K. (2008). Construction contract risk management: A study of practices in the United Kingdom. Cost Engineering, 50(1), 22-33.

Agyakwa-Baah, A. (2009). A study into risk assessment and management practices within Ghanaian medium and large construction organizations. Unpublished MSc Project Management Dissertation, Built Environment Department, Sheffield Hallam University, United Kingdom.

Adu Gyamfi, T. and Boadaa, R. (2015). The effect of procurement management practices on risk management in construction firms. International journal of science: Basic Applied Research, vol.24 (3), 403 - 420.

Akintoye, A. S., \& Macleod, M. J. (1997).Risk analysis and management in construction.International Journal of Project Management, 12(1), 31-38. 
Al-Bahar, J., \& Crandall, K. (1990).Systematic risk management approach for construction projects.ASCE Journal of Construction Engineering and Management, 116(3), 533-545.

Assibey-Mensah, G. O. (2008). Ghana's construction industry and global competition: A research note. Journal of Black Studies, 39, 974-89.

Babbie, E. (2005). The basics of social research. Belmont: Thomson Wadsworth.

Bernstein, B. (1999) Vertical and horizontal discourse: an easy. British journal of sociology of Education, 6(2) 2030.

Buertey, J. I. T., Abeere-Inga, F., \&Kumi, T. A. (2012). Practical application of risk management techniques in infrastructural delivery: A case study of Ghanaian construction industry. Journal of Construction Project Management and Innovation, 2(1), 224 - 244.

Carter, R. L., \& Doherty, N.A. (1974).Handbook of risk management. London: Kluwer-Harrap Handbooks.

Chapman, C., \& Ward, S. (1997). Project risk management: Process techniques and insights. England: John Wiley and Sons Ltd.

Chapman, R. J. (2001). The controlling influences on effective risk identification and assessment for construction design management. International Journal of Project Management, 19(3), 147-160.

Chileshe, N., \&Yirenkyi-Fianko, A. B. (2011). Perceptions of threat risk frequency and impact on construction projects in Ghana: Opinion survey. Journal of Construction in Developing Countries, 16(2), 115-149.

Chileshe, N. (2004). The application of TQM within small and medium sized construction related organizations. Unpublished PhD Thesis, School of Construction, Sheffield Hallam University, Sheffield, UK.

Claycamp, H. G. (2012). Probability concepts in quality risk management. Journal of Pharmacy, Science and Technology, 66(1), 78-89. doi: 10.5731/pdajpst.2012.00801.

Creswell, J. W. (2003) Research design qualitative, quantitative and mixed method approaches second edition. Sege publication califonia.

Dadzie, J., Abdul-Aziz, A. R., Kwame, A. (2012). Performance of consultants on government projects in Ghana: Client and contractor perspective. Journal of Business, 2(6), 256-267

Ehsan, N., Alam, M., Mirza, E., \&Ishaque, A. (2010).Risk management in construction industry.Journal of Production and Performance Management, 61(2), 173-193

Ehsan A., Anjelo, F. D., Kujur, F. E., \&Chaudhary, M. (2014). Risk management strategies for accidental risk occurrence on construction sites: A case study of Allahabad. Journal of Academia and Industrial Research, 3(2), 8991.

Flanagan, R., \& Norman, G. (1993).Risk management and construction. London: Blackwell Science Ltd.

Frimpong, Y., Oluwoye, J., \& Crawford, L. (2003). Causes of delay and cost overruns in construction of groundwater projects in developing countries: Ghana as a case study. International Journal of Project Management, 21, 321-26.

Ghahramanzadeh, M. (2013). Managing risk of construction project a case study of Iran. Retrieved on October 20, 2014 from http://www.riskmanagementinsight.com/media/docs/FAIR_introduction.pdf

Godfrey, P. (1996). Control of risk: A guide to the systematic management of risk from construction. London: Construction Industry Research and Information Association.

Hassanein A. G., \&Afify, H. M. (2007). Contractor's perceptions of construction risks: A case study of power station projects in Egypt. Cost Engineering, 49(5), 25-34.

Hayes, R., Perry, J., \& Thompson, J. (1986).Risk management in engineering construction: a guide to project risk analysis and risk management. London: Thomas Telford.

Hillson, D., \& Murray-Webster, R. (2004).Understanding and managing risk attitude. Accessed on September 16, 2014 from http://www.kent.ac.uk/scarr/events/finalpapers/Hillson\%20\%2B\%20Murray-Webster.pdf

Hopkin, P. (2012). Fundamentals of risk management (2nd ed.). London: Kogan-Page.

Hubbard, H. (2009). The failure of risk management: Why it's broken and how to fix it.Chichester: John Wiley \& Sons. 
Ijaola, I. (2012). An analysis of contractors' approaches to risk management practices in Lagos state, Nigeria. In S. Laryea, S.A. Agyepong, R. Leiringer, and W. Hughes, (Eds), Proceedings of the 4th West Africa Built Environment Research (WABER) Conference,24-26 July 2012, Abuja, Nigeria, pp. 687-695.

Jean-Lou, C. M., Dorne, G. E. N., Kass, L. R., Bordajandi, B. A., Ulla B., Castoldi, A. F., Heppner, C., Eskola, M., Fabiansson, S., Ferrari, P., Scaravelli, E., Dogliotti E., Fuerst, P., Boobis, A. R., \& Verger, P. (2011). Human risk assessment of heavy metals: principles and applications. In S. Astrid, S. H, S.

Jones, J. A. (2006). An introduction to factor analysis of information risk (FAIR).Retrieved on October 14, 2014 from http://www.riskmanagementinsight.com/media/docs/FAIR_introduction.pdf

Key, J. P. (1997). Qualitative research. Retrieved July 24, 2007, from

http://www.okstate.edu/ag/agedcm4h/academic/aged5980a/5980/newpage21.htm

Kishk, M., \&Ukaga, C. (2008).The impact of effective risk management on project success. Proceedings of the $24 \mathrm{th}$ Annual ARCOM Conference, 1-3 September 2008, Cardiff, UK, Association of Researchers in Construction Management, (pp.799-808).

Krejcie, R. V. and Morgan, D. W. (1970) Determining the sample size for research activities. Journal of Educational and psychological measurement, (30) 607-610.

Laryea, S. (2011).Risk accountability in the tender process of contractors in Ghana and UK. International Journal of Project Organisation and Management, 3 (3-4), 290-306.

Mumtaz, M. M., Hugh, H., \& Hana, P, R. (2011). Mixtures and their risk assessment in toxicology. In S. Astrid, S. H, S. K. O. Roland. (Eds.), Metal ions in toxicology. RSC Publishing (pp.61-80).

R. Müller, "Leadership Competences in Projects," in Advanced Project Management, T. Mayer, R. Gleich, A. Wald and R. Wagner, Eds., Münster, Lit-Verla, 2010

Noor, I., \&Tichacek, R. (2009). Contingency Misuse and other risk management pitfalls. Cost Engineering, 51(5), 28-33.

Odonkor, A. K. (2011).The effect of strategic risk management on project delivery: A case study of the construction industry in Ghana.Unpublished thesis for Commonwealth Executive Master of Business Administration Institute of Distance Learning, KNUST

Oladinrin, O., Olatunji, A., \&Hamza, B. (2013).Effect of selected procurement systems on building project performance in Nigeria.International Journal of Sustainable Construction Engineering and Technology, 4(1), 12-23.

Panthi, K., Ahmed, S., Ogunlana, S. (2009). Contingency estimating for construction projects through risk analysis. International journal of construction education and research, 5, 79-94.

Perera, B., Dhanasinghe, I., \&Rameezdeen, R. (2009). Risk management in road construction: the case of Sri Lanka. International Journal of StrategicProperty Management, 13, 87-102.

Popova-Clark, J. (2011). Risk management: Better, but still not there yet. Retrieved on February 15, 2014 from http://www.dataanalytics.com/pdf/BetterRiskMgt.pdf

Pourrostam, T., \& Ismail, A. (2011).Significant factors causing and effects of delay in Iranian construction projects.Australian Journal of Basic and Applied Sciences, 5(7), 450-456.

Project Management Institute (PMI). (2004). Project management body of knowledge (3rd ed.). New York: Project Management Institute, Inc.

Proske, D. (2008). Catalogue of risks: Natural, technical, social and health risks. Mount St. Helens, Washington: Springer

Razaque, A., Bach, C., Salama, N., \&Alotaibi, A. (2012).Fostering project scheduling and controlling risk management.International Journal of Business and Social Science, 3(14), 12-26.

Sarantakos, S. (1998). Social research $2^{\text {nd }}$ edition. Basingstoke, Macmillan.

Sarantakos, S. (2005). Social research. Hampshire: Palgrave Macmillan.

Smallman, C. (1999). Risk and organizational behavior: A research model. Disaster Prevention and Management, 5(2), 12-26.

Smith, G., \& Bohn, C. (1999).Small to medium contractor contingency and assumption of risk.Construction Engineering and Management, 125(2), 101-108. 
Smith, A, Mortledge, R., \& Kashiwagi, D. T. (2006). Building procurement. Oxford, U.K: Wiley Blackwell

Smith, N. J. (2003). Appraisal, risk and uncertainty. London: Thomas Telford Ltd.

Sarantakos, S. (1998). Social research $2^{\text {nd }}$ edition. Basingstoke, Macmillan.

Sarantakos, S. (2005). Social research. Hampshire: Palgrave Macmillan.

Sohizadeh, R., Hassanzadeh, M., Raddum, H., \& Hole, K. J. (2011).Quantitative risk assessment. Bergen: University Of Bergen. Retrieved on February 15, 2013 from http://www.nisnet.no/filer/Finse11/Risk\%20Assessment.pdf

Wang, S. Dulaimi, M., \&Aguria, M. (2004). Risk management framework for construction projects in developing countries. Construction Management and Economics, 22, 237-252

Ward, S., \& Chapman, C. (2003). Transforming project risk management into project uncertainty management. International Journal of Project Management, 21(2), 97-105

Wiguna, I .P. A., \& Scott, S. (2006).Relating risk to project performance in Indonesian building contracts.Construction Management and Economics, 24(11), 1125-1135.

Zou1, P. X. W., Zhang, G., \& Wang, J-Y. (2006). Identifying key risks in construction projects: Life cycle and stakeholder perspectives. Retrieved on February 15, 2013from

http://www.prres.net/papers/Zou_risks_in_construction_projects.pdf 